University of Nebraska - Lincoln DigitalCommons@University of Nebraska - Lincoln

2018

INDIAN BASKETRY IN YOSEMITE VALLEY, 19th-20th Century: Gertrude "Cosie" Hutchings Mills, Tourists and the National Park Service

Catherine K. Hunter

Follow this and additional works at: https://digitalcommons.unl.edu/tsaconf

Part of the Art and Materials Conservation Commons, Art Practice Commons, Fashion Design Commons, Fiber, Textile, and Weaving Arts Commons, Fine Arts Commons, and the Museum Studies Commons 


\section{The Social Fabric: Deep Local to Pan Global}

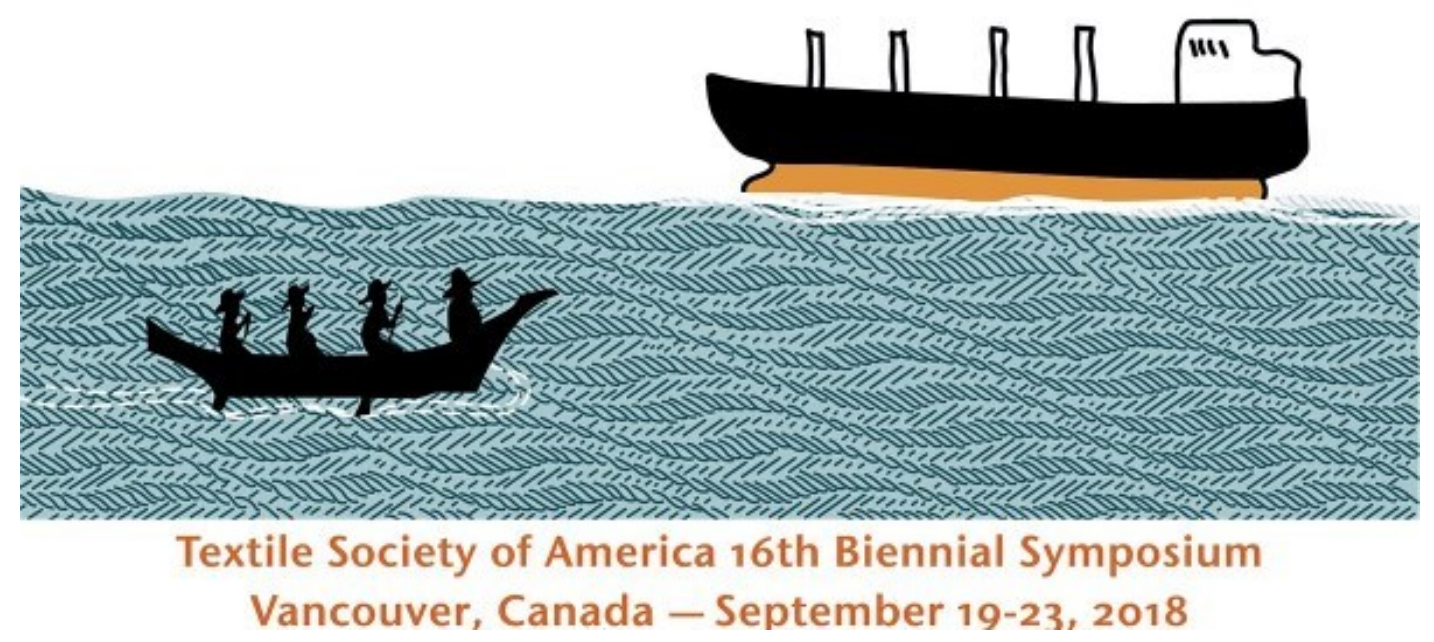

Published in Textile Society of America Symposium Proceedings 2018

Presented at Vancouver, BC, Canada; September 19 - 23, 2018

https://digitalcommons.unl.edu/tsaconf/

Copyright $@$ by the author(s). 


\title{
INDIAN BASKETRY IN YOSEMITE VALLEY, 19th-20th Century:
}

\section{Gertrude "Cosie" Hutchings Mills, Tourists and the National Park Service}

\author{
Catherine K. Hunter
}

\section{Background}

The theme of the Textile Society of America's Symposium 2018 "The Social Fabric: Deep Local to Pan Global" addresses the impact of immigration and settlers on an already long-inhabited land and how textile traditions were influenced by cultural contact. My topic is American Indian basketry in Yosemite Valley, Central California, and the changes that occurred due to contact with settlers, immigrants and tourists in the nineteenth and twentieth centuries. This story requires an understanding of local, regional and national history.

I selected this topic because of the Hutchings Mills Collection at the Robert S. Peabody Institute of Archaeology, Andover, Massachusetts. Collector and donor Gertrude "Cosie" Hutchings Mills (1867-1956) was one of the first Anglo-American children born in Yosemite Valley to early settlers James Mason and Elvira Hutchings. Gertrude collected baskets before 1900, recording many acquisition sites and the names of three weavers; such documentation is very rare. After marriage to William Elligood Mills in 1899, they moved to New England. In 1937 the collection was donated to the Robert S. Peabody Institute of Archaeology on the campus of Phillips Academy, a college preparatory boarding school where their eldest son was a student.

In 1978, Craig D. Bates, Indian Cultural Program Specialist at the Yosemite Museum, inquired about the Hutchings Mills collection. In 1986, Curator David M. Forgang asked if the collection could be transferred to the Yosemite Museum because, "Mrs. Mills' father was an early settler here in Yosemite and this collection of baskets, dating from mid-to-late century, is the single most important assemblage from that early period." The collection was made available for study in Andover but never traveled to Yosemite.

In 1990, Craig D. Bates, Curator of Ethnography at Yosemite Museum, and Martha J. Lee, Assistant Curator, published Tradition and Innovation: A Basket History of the Indians of the Yosemite-Mono Lake Area. The Hutchings Mills Collection is mentioned and one basket by Dulcie Beal (1846-1926) is illustrated. ${ }^{2}$

The Robert S. Peabody Institute of Archaeology's online catalog includes 56 objects in the Hutchings Mills Collection. The accession numbers are 18/1548 through 18/1605 (https://peabody.pastperfectonline.com/ ).

\section{Introduction: Baskets as Material Culture}

Baskets are ingenious objects that reflect a deep understanding of natural materials. Made for ceremony, utility and trade, they are artifacts of material culture enriched with a myriad of

\footnotetext{
${ }^{1}$ David M. Forgang, Collection Notes, Accession Number 18. Robert S. Peabody Institute of Archaeology

${ }^{2}$ Craig D. Bates and Martha K. Lee, Tradition and Innovation: A Basket History of the Yosemite-Mono Lake Area (Yosemite National Park, CA: The Yosemite Association, 1990), 4 and 135.
} 
human associations. While basket makers continuously draw upon ancient traditions, new forms and designs emerged steadily in response to contact with others and individual creativity.

The single word basket does not capture the variety in form and function. Before contact the largest group of baskets served as a portable kitchen for itinerant people. Beautiful work baskets made by women honored food and its value to sustain life.

Specialized baskets were designed for gathering and processing seeds and especially acorns, a dietary staple rich in protein, fat and starch. A burden basket for gathering and carrying is a hollow cone, two to three feet high with a pointed base and round rim. A seed beater is a bowl with a short handle that was used to beat shrubs in order to release seeds into the basket. The burden basket is carried on the back, supported by a tumpline around the basket and across the shoulders or forehead. Concave trays were used for winnowing, drying and sifting.

Most surprising is the practice of cooking with baskets. To boil water, heated stones were lifted continuously into water-filled baskets. Satisfaction with this method may explain the lack of ceramic cooking containers among some tribes of California. The introduction of metal cooking containers would interrupt this practice; eventually kitchen baskets would become obsolete.

Other types of baskets carried babies, facilitated formal occasions, functioned as trays for games and gambling, trapped fish and birds, stored possessions, carried water, and more. They were essential to live in this world and the next, as indicated by the practice of burying or destroying baskets as part of a woman's death rite.

Finally, the cultural value of baskets is clear because they appear in ancient stories. The following Miwok myth is a supernatural account of creation in which ancestors and their baskets were transformed into geological features of Yosemite Valley:

Long before the Yo-ho-meh-tik' Indians lived in Ah-wah'-nee, the Yosemite Valley, there were many bird and animal people there. One of them went to Mono Lake and married an Indian woman named Teh-sa-ahk'. He started to bring his bride back to Ah-wah'-nee to live. The husband carried a roll of deer skins on his back and held a staff in his hand. Teh-sa-ahk' had a baby cradle in her arms and Chee-keh-leh', the pointed carrying basket, on her back. They came by Tenaya Lake. The old Indians say that you can still see the tracks of Teh-sa-ahk', the Mono woman, along the shore of the lake. At Mono Lake there were no trees, and she thought that all the oak trees and other plants along the trail were beautiful She picked up some acorns and other seeds and threw them in the Chee-keh-leh', or carrying basket, on her back. When the travelers came to where Ah-wy'ee, the Mirror Lake, is now, the new husband quarreled with Teh-sa-ahk'. She wanted him to return with her and live at Mono Lake. He said there were no oaks or other trees there. Said she, "I will take these acorns and seeds along and we can plant trees." But her husband failed to listen to her plea.

Finally Teh-sa-ahk' began to cry and ran back along the trail towards her people at Mono Lake. Then the husband became angry. He cut a tree limb and ran after his runaway wife, beating her severely. Teh-sa-ahk' also became angry at her husband and threw 
Chee-keh-leh', the carrying basket, at him. This basket turned to stone and became Basket Dome. Still running, Teh-sa-ahk' threw the [hooded] baby cradle at her husband. It also turned to stone and became Choo-ko-neh', the Royal Arches. Because of their anger both Teh-sa-ahk' and her husband were turned to stone. The husband became North Dome, which the Indians called To-ko-yee.' The wife became Half Dome, which the Indians call Teh-sa-ahk' even to this day. The Mono women bob their hair and cut it in bangs. Half Dome looks just like the head and shoulders of a Mono woman. Since the quarrel Teh-sa-ahk' has always been sorry. The old Indians say that the tears she has shed formed Ah-wy'-ee, the Mirror Lake. You can still see the marks of these tears where they ran down the face of Teh-sa-ahk,' the Mono Indian bride, which the white people call Half Dome. ${ }^{3}$

Basketry provides an enduring link from the ancient era to recent history. The period from 1860 to 1930 was the peak of collecting basketry by tourists and collectors. This study begins mid-nineteenth century and presents highlights of local and national history, changes to Indian culture and baskets due to contact, the story of Gertrude "Cosie" Hutchings Mills, and efforts to revitalize basketry. Only baskets in the Hutchings Mills Collection will be used as examples.

\section{The Era and the Setting 1850 to 1930s: California enters the Union 1850, Mariposa War 1850-51, Homestead Act 1862, Yosemite Grant Act 1864, Picturesque America 1872, Yosemite National Park 1890, National Park Service 1916}

The 19th century was a dynamic time for the United States. California joined the Union in 1850. The philosophy of Manifest Destiny stimulated westward expansion. The Industrial Revolution powered the economy and the transcontinental railroad was completed in 1869. The country struggled to recover after the Civil War's end in 1865. Nationalism grew and historic

preservation of land became a movement. Land Grants and the Homestead Act of 1862 provided unpaid soldiers, immigrants and the federal government with the right to free land taken from American Indians who suffered forced removal, death and callous disregard.

The setting for this study is Yosemite Valley in the Sierra Nevada mountain range of Central California, two hundred miles east of San Francisco. Due to its remote location, contact with Indians was limited until there was an epic influx of thousands of immigrants for the Gold Rush of 1848. Contact would set in motion irreversible changes to the land and culture of the Indians. Baskets reflect change locally, regionally and nationally.

As miners and settlers seized and developed land, they destroyed life-sustaining natural resources, polluted rivers, depleted the supply of wild animals and plants, and obstructed pathways of people who were self-sufficient as hunters, gatherers, fishermen and traders. Indians suffered attack, kidnapping, rape, murder, enslavement, disease, starvation, loss of land and endless indignities. In response, Indians raided settlements and friction grew into the Mariposa War of 1850-1851.

The state of California authorized a militia of volunteers called the Mariposa Battalion to subdue and force Indians out of the region. Baskets were destroyed as a military strategy to encourage

\footnotetext{
${ }^{3}$ William Turnbaugh and Sarah Peabody Turnbaugh, Baskets of the Grandmothers: American Indian Baskets in Myth and Legend (Peace Dale, RI: Thornbook Publishing, 1999), 122-123.
} 
starvation. In the following excerpt from his book Discovery of the Yosemite (1892), Dr. Lafayette Bunnell is callous when authorizing the destruction of huts, food and baskets yet sharply astute while describing the ingenious variety of baskets:

It was therefore decided that the best policy was to destroy their huts and stores, with a view of starving them out, and of thus compelling them to come in and join with Ten-ie-ya and the people with him on the reservation. At this conclusion the destruction of their property was ordered, and at once commenced. While this work was in progress, I indulged my curiosity in examining the lodges in which had been left their home property, domestic, useful and ornamental. As compared with eastern tribes, their supplies of furniture of all kinds, excepting baskets, were meagre enough.

These baskets were quite numerous, and were of various patterns and for different uses. The large ones were made either of bark, roots of the Tamarack or Cedar, Willow or Tule. Those made for gathering and transporting food supplies, were of large size and round form, with a sharp apex, into which, when inverted and placed upon the back, everything centers. This form of basket enables the carriers to keep their balance while passing over seemingly impassable rocks, and along the verge of dangerous precipices. Other baskets found served as water buckets. Others again of various sizes were used as cups and soup bowls; and still another kind, made of a tough, wiry grass, closely woven and cemented, was used for kettles for boiling food. The boiling was effected by hot stones being continually plunged into the liquid mass, until the desired result was obtained... The water baskets were also made of wire-grass; being porous, evaporation is facilitated, and like the porous earthen water-jars of Mexico, and other hot countries, the water put into them is kept cool by evaporation. ${ }^{4}$

In summary, the Mariposa Battalion facilitated the development of Yosemite Valley by removing a majority of the Indians and reporting news of a superbly beautiful valley to the public.

\section{Discovery and Development of Yosemite Valley}

Intrigued by reports of Yosemite Valley by the Mariposa Battalion, James Mason Hutchings is credited with leading the first documented tourists into Yosemite in 1855. Hutchings, a publisher and promoter, recognized the potential for tourism and launched a monthly periodical Hutchings' Illustrated California Magazine from 1856 to 1861 with his own accounts of Yosemite in the first edition. He was among the entrepreneurs who moved to Yosemite to open hotels, plant gardens and orchards, plow hay fields, raise sheep and livestock, fence pasture, build roads, and clear trails. James and Elvira Hutchings seized 160 acres, the maximum land grab authorized for an individual by the Homestead Act of 1862 and opened Hutchings House for guests in 1864.

On June 30, 1864, President Abraham Lincoln signed the Yosemite Grant Act authorizing the federal government to seize Yosemite Valley and the Mariposa Grove of sequoia trees for the

\footnotetext{
${ }^{4}$ Lafayette H. Bunnell, Discovery of the Yosemite. (New York, NY: F. H. Revell Company, 1892), Chapter V.
} 
State of California entirely for the enjoyment of citizens. As the first scenic public park designated by the federal government, but not yet managed or funded by the federal government, Yosemite is viewed as the birthplace of the national park system. Twenty-six years after the Yosemite Grant Act, in 1890, Congress created Yosemite National Park encompassing wilderness surrounding the state-managed Yosemite Valley and Mariposa Grove.

One year later, Indians could no longer repress their outrage over treatment of the land and themselves. With help from sympathetic settlers, they issued the Yosemite Indian Petition of 1891 to the President and Congress. The petition recalls in punishing detail the tyranny of the miners, attacks by the Mariposa Battalion, and destruction of land by domesticated animals and men. Acutely aware of their diminished status, the Indians describe themselves as "poorly-clad paupers and unwelcome guests, silently the objects of curiosity or contemptuous pity to the throngs of strangers who yearly gather in this our own land and heritage." 5 The federal government never responded to their request for compensation for damages to their homes and way of life.

Sixteen years later, in 1906, the Yosemite Valley and Mariposa Grove reverted entirely to federal control as Yosemite National Park. Ten years later, management was transferred to the National Park Service when it was founded in 1916.

The most important detail for this study is that Yosemite was the first and only National Park that permitted Indians to work and live within its boundaries until the 1930s. Early park management accepted the Indians as non-combative laborers with a right to remain in the park, and tourists treated them as curiosities and entertainers whose presence fulfilled their romanticized expectations during a wilderness experience. Indians who survived the Mariposa War were a primary source of labor in the park.

To imagine the American citizen's point of view in the late 19th century, look to a remarkable travelogue, edited by James Cullen Bryant, a poet and journalist. The title is Picturesque America; The Land We Live In, A Delineation by Pencil and Pen: The mountains, rivers, lakes, forests, water-falls, shores, canons, valleys, cities, and other picturesque features of our country (1872). ${ }^{6}$ The work was published as a subscription, then bound into two volumes. Illustrated with 900 wood engravings and 50 steel engravings, the books inspired nationalism, as well as active and armchair tourism, while describing unspoiled and pastoral scenery to rival that of Europe. The publication date of 1872 coincides with the establishment of Yellowstone National Park as the first National Park in the United States, eight years after the Yosemite Grant Act.

In Volume I there is a 30 page chapter (out of 568 pages) devoted to "The Yosemite" with 20 illustrations and information about arduous travel conditions, friction between miners and Indians in 1851, conflict with the Mariposa Battalion, James Mason Hutchings guiding the first tourists, the Land Grant creating a public park, sequoias, tree varieties, facilities and entertainment for tourists, and colorful descriptions of scenery. The "slaughter" 7 of Indians in

\footnotetext{
${ }^{5}$ Yosemite Indian Petition to the United States, c. 1891. http://www.yosemite.ca.us/library/yosemite_indian_petition_to_the_us.html.

${ }^{6}$ William Cullen Bryant, Picturesque America or The Land We Live In, Volume 1 (New York, NY: D. Appleton and Company, 1872).

${ }^{7}$ Ibid., 465.
} 
1851 was dismissed in a sentence and observations of the Indians' appearance and behavior are not complimentary, but the processing of acorns into food using baskets is a compelling topic covering several pages.

One engraving presents a gathering of Indians who are cooking and eating chemuck or acorn porridge. ${ }^{8}$ They wear fabric shirts and toga-like garments at a time when citizen style dress had been adopted. The details include a conical burden basket on the ground beside a sand basin where acorn flour was rinsed repeatedly to remove bitter tannin, water-filled cooking baskets standing upright on the sand, basket food bowls, and a sawiya (a length of wood bent and tied) being used to lift hot stones from a fire into the cooking basket to boil water. Kitchen baskets that were destroyed as a war strategy 22 years earlier by the Mariposa Battalion had become attractions for tourists.

\section{Basketry: Changes Due to Contact and Collecting Trends}

To study changes in basketry, it is necessary to recognize the following categories: baskets made and used by one community, trade baskets acquired from other communities, and new forms and designs made for the Euro-American marketplace. While forms, materials, colors and established patterns represent tribal affiliations and traditions, basketry after contact changed to represent two cultures - Indians and Euro-Americans.

To identify baskets of specific tribes and traditions, it is essential to identify natural materials which are regionally specific (and sometimes shared when transported by horse, automobile and the US Postal Service), as well as to study structures and finishes that represent cultural preferences. For example, the "start" (or beginning) and rims, as well as the direction of weaving, are indicators of cultural practices. For immersion in the technical and design analysis of California Indian basketry, I recommend three volumes published by Ralph Shanks.

Indians who survived the Mariposa War were essentially de-populated and dislocated immigrants in their own territory. In Yosemite Valley, the federal government intervened with treaties to hasten re-location to reservations. Indians who avoided re-location and re-settled Yosemite Valley were a blend of Ahwahneechee of Yosemite Valley, Mono-Paiutes from Eastern Sierra Nevada, Miwok from the South Sierra, and Yokuts from the Central Valley, each with a distinctive language. As the tribes co-existed and inter-married, basket makers shared materials, techniques and distinctive cultural practices, possibly stimulating changes in basketry.

The most significant cultural change for Indians, due to contact with Euro-Americans, was the loss of the traditional indigenous culture and subsequent adaptation to a new way of life. Itinerant tribes and families were separated and forced into a sedentary life style with permanent dwellings and new conventions in foodways, clothing, governance, and a cash economy.

Basket makers adapted in the changing world. Baskets were accepted as barter before they were purchased by settlers who appreciated their utility and beauty. When subsistence living was no longer possible, basket makers were forced to seek paid employment as domestics at hotels and

\footnotetext{
${ }^{8}$ Bryant, Picturesque America, 482.
} 
homesteads. When metal pots replaced cooking baskets, basket makers actively seized the opportunity to make baskets for a new marketplace.

Women were the primary baskets makers in addition to caring for their own families and working as domestics or maids. While men were employed as laborers, hunters, fishermen and guides, their basket making was limited to traps for fish and birds, and possibly cradle baskets. The collection includes an open work basket designed to carry fish (Acc. No. 18/1592) and a cradle board (Acc. No. 18/1602) that were possibly made by men.

Basketry in the Yosemite marketplace was a brilliant success from 1890 to 1930; however, the relationship between the Indians and Euro-Americans presented a fascinating dichotomy. On one hand, accomplished basket makers in remote Yosemite Valley seized an economic opportunity to design baskets for a society that treated Indians cruelly, seized their land, and continued to discourage indigenous language, traditions, and values. On the other hand, in denial over the destruction of Indians, citizens made great efforts to embrace the culture of Indians by collecting curios and basketry. The latter effort required minimal personal contact with Indians and effectively restricted Indians to the cultural imagination of Americans. Co-existence was surely challenging; however, basket makers adapted out of necessity.

Why were the Euro-American settlers and immigrants so captivated by Indian basketry? The reasons include artistry, fascination with Indians and the era. Baskets were well-made, useful and beautiful. Handsome designs were made with dyed materials and structural patterning, unlike Old World types that were made of wood splints, coarsely coiled grasses or interlaced willow. Baskets made by the vanishing Indians of the wilderness were exotic and stimulated the imagination of citizens in the unsettling dynamic era of the 19th century. Contrary to expectations, Indians did not vanish; rather, basket makers responded creatively when clients presented a market for traditional and new baskets.

Several collecting trends amongst tourists fueled a demand for basketry. James Mason Hutchings published annual attendance figure from 1864 to 1886 in his book In the Heart of the Sierras. ${ }^{9}$ With completion of the transcontinental railroad in 1869, Yosemite welcomed over 1,112 visitors, and over 4,000 in 1886. In the twenty-first century the National Park Service reports an average of four million visitors annually.

After settlers, there were the ever increasing numbers of tourists from across the country. In the second half of the nineteenth century, urbanized tourists adopted the popular romantic outlook of Indians as a noble and vanishing race. Proponents of the Arts and Crafts Movement appreciated the aesthetic of natural materials and geometric designs in baskets that were handmade under pre-industrial conditions. In late Victorian times, baskets were admired as the first women's art before the invention of pottery and textiles. Zealous collectors of cultural objects as status symbols, Victorians sustained a fad known as Basket Mania and filled cabinets, corners of rooms or entire rooms with Native American objects including basketry.

While baskets connected Indian women to their ancestors, traditions and subsistence activities prior to contact, baskets for the marketplace linked Indian women to the world beyond Yosemite

\footnotetext{
9 James M. Hutchings, In the Heart of the Sierras. 1881, Chapter X. $\mathrm{http}: / /$ www.yosemite.ca.library/om_the_heart_of_the_sierra.
} 
transcending the limitations of gender, geography and society. Baskets from remote Yosemite Valley were collected by the elite society of America.

\section{Gertrude "Cosie" Hutchings Mills (1867-1956)}

According to Bates and Lee, the most significant Yosemite Valley basket collections prior to 1900 were assembled by residents. Gertrude "Cosie" Hutchings may have been the first to document acquisition locations and names of artists.

Shirley Sargent tells the detailed story of Gertrude in Pioneers in Petticoats: Yosemite's Early Women 1856-1900. ${ }^{10}$ James Mason and Elvira Hutchings opened the Hutchings Hotel in 1864. Gertrude and her older sister were the first Anglo-American children born in Yosemite Valley. When Gertrude was eight years old in 1875, homestead claims were revoked, the family was evicted and returned to San Francisco where they lived with Elvira's mother Florantha T. Sproat. After the parents divorced, Sproat took over care of the children. One can speculate that Gertrude's basket collecting and the family's positive relationships with the Yosemite Indians were influenced by Sproat's experience as a teacher in the Ojibway Indian Mission at La Pointe, Wisconsin.

When James Mason Hutchings was invited to return as Guardian of Yosemite in 1880, Gertrude was 13 years old. Subsequently, she lived in San Francisco, Yosemite, and the Pennsylvania when she attended Swarthmore College 1889-1891; earned her Mariposa Teaching Certificate in 1891, at age 24, the same year as the Indian Petition; taught the children of settlers and Indians in the Wawona School District for six years; and attended Stanford University as an English major in 1894. She was also employed at times as a pack train supervisor, telegraph operator, stagecoach driver, and Postmistress of Yosemite Valley. Her final job in the valley was custodian of the Sierra Club rooms before marriage in 1899, at age 32, to William Elligood Mills. Gertrude "Cosie" Hutchings was known throughout the region as the daughter of early settlers, a school teacher and jill-of-all-trades. In fact, she lived there off and on through her 89 years. A memorial marker at the park identifies her as "Daughter of Yosemite.". 11

Gertrude's handwritten notes at the Robert S. Peabody Institute of Archaeology reflect her passion for basketry. She describes basketry materials, the processing of acorns into food, types of baskets, and an awareness of basketry in American literature. She recorded the following excerpt from Washington Irving's Astoria (1836), an account of the Hunter expedition across the Rockies 1810-1811, speaking of the Umatilla Indians of Eastern Oregon:

Though they might have two or three brass kettles (obtained from the English Fur Co.) hanging in their lodges, yet they would frequently use vessels made of willow for carrying water, and would even boil their meat in them by means of hot stones... The women wore caps of willow neatly worked and figured. ${ }^{12}$

\footnotetext{
${ }^{10}$ Shirley Sargent, Pioneers in Petticoats: Yosemite's Early Women 1856-1900 (Yosemite, CA: Flying Spur Press, 1966), 33-40.

${ }^{11}$ Find A Grave. https://www.findagrave.com/memorial/8471304/getrude-mills.

12 Gertrude "Cosie" Hutchings Mills, Collection Notes, Accession Number 18. Robert S. Peabody Institute of Archaeology.
} 


\section{Change in Basketry: Examples in the Hutchings Mills Collection}

The repertoire of highly skilled and creative basket makers in Yosemite Valley ranged from replicas of earlier baskets with designs inherited from ancestors to completely new forms with designs copied from Euro-American culture. Approximately one-fifth of the collection represents baskets made for sale.

The most obvious design change is the adoption of non-traditional figurative motifs attributed to contact with books, periodicals, catalogs, and needlework patterns, as well as carpets and calico. Examples include a small Maidu bowl with stylized butterflies and plants (Acc. No. 18/1583) and an oval Miwok container with designs suggesting linked bows or bells (Acc. No. 18/1581). From Southern California, there is a bowl with the motif "25" (Acc. No. 18/1556) repeating around the circumference. In the latter example, we wonder if the maker was copying a " 25 ", or " 2 " and its mirror image, with or without recognizing them as numerals in Euro-American culture.

Design changes were also influenced by Indian beadwork. The best example is a large bowl (Acc. No. 18/1558), Yuki or Maidu in origin that combines traditional "block" designs and innovative "free-floating" designs that resemble small chandeliers. The block design is made of stacks of overlapping parallelograms, and free-floating designs appear in the empty space between the blocks. This innovation in design has been traced to beadwork from Eastern Woodlands Indians involved in the fur trade. In turn, beadwork designs may have had their origin in Canada, Eastern United States and Europe. ${ }^{13}$

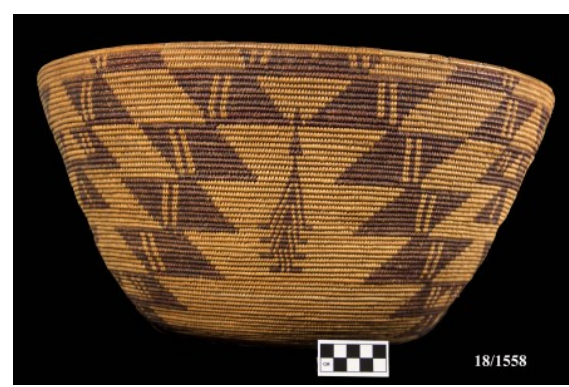

Cooking basket (Acc. No. 18/1558) with "block" and "free-floating" designs. (C) Robert S. Peabody Institute of Archaeology, Phillips Academy, Andover, Massachusetts. All Rights Reserved.

Among the most intriguing new forms are two fancy pedestal baskets that are compound baskets assembled from several parts. More research is needed to determine if the pedestal form was inspired by the religious chalice, secular goblet, stemware or fashionable serveware such as pedestal, compote or centerpiece bowls of glass or silver for serving or displaying food.

\footnotetext{
${ }^{13}$ Ralph Shanks, Indian Baskets of Northern California (Seattle, WA: University of Washington Press, 2015 ), 83.
} 

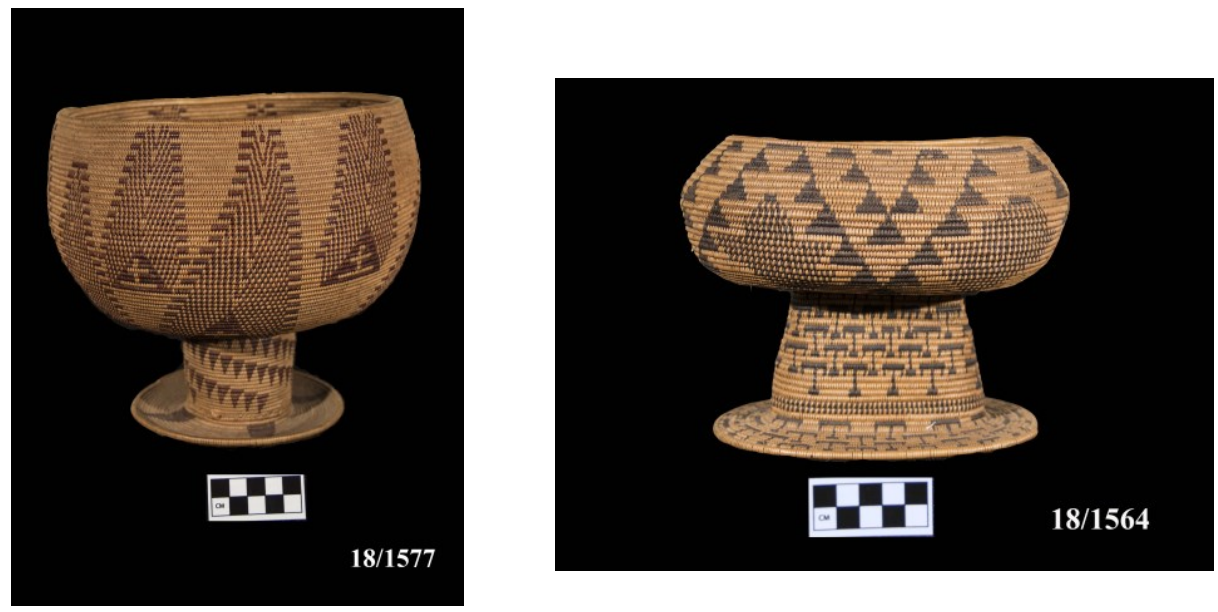

Pedestal baskets: Acc. No. 18/1577 (left) and Acc. No. 18/1564 (right).

(C) Robert S. Peabody Institute of Archaeology, Phillips Academy, Andover, Massachusetts. All Rights Reserved.

The larger pedestal basket (Acc. No. 18/1577) of Maidu origin, 8.25 inches $(21 \mathrm{~cm})$ high, has a round bowl with repeating designs that suggest pine trees. At the foot of each tree is a motif resembling two variants of Christian crosses. If the maker observed religious crosses or literature introduced by the Spanish missionaries, the motifs may be interpretations of the patriarchal cross (two horizontal bars) and the papal cross (three horizontal bars).

The smaller pedestal basket (Acc. No. 18/1564) of Maidu or Pomo origin, 6 inches $(16.5 \mathrm{~cm})$ high, has repeating designs that suggest a maple leaf on the oval bowl and a stylized " $\mathrm{T}$ " on the pedestal. The latter may be another Christian cross variant, possibly the Franciscan Tau. Gertrude Hutchings identified the artist as Mary Hamilton, Maidu, of American Valley in Plumas County. Photographs of the artist are available in the archives of Grace Nicholson at the Huntington Library, San Marino, California.

Among cooking baskets, one Paiute example (Acc. No. 18/1566) has pattern rows that were painted. It was tempting to imagine that painting was a time-saving practice on baskets made for sale until I found that this technique was a traditional cultural practice among some Indians of the Great Basin to the east of Yosemite. ${ }^{14}$

Another innovation is seen in a small storage container (Acc. No. 18/1588) from Southern California with a tight-fitting lid, when traditional Indian baskets rarely had lids.

Indians made small utilitarian baskets for girls to play with and practice cultural roles; however, similar examples could have been made for sale. The collection includes two small cradles less than one third the length of a full size 40 inch $(102 \mathrm{~cm})$ cradle (Acc. No. 18/1562). The sitting cradle (Acc. No. 18/1579) from Northern California is 14 inches $(35 \mathrm{~cm})$ long and the lying cradle (Acc. No. 18/1593) of Miwok or Paiute origin is 16 inches $(41 \mathrm{~cm})$ long. A small Miwok seed beater (Acc. No. 18/1601) is less than half the length of the of a full-size seed beater (Acc. No. 18/1580). Collectors in California stimulated a new demand for miniature baskets; in the

\footnotetext{
${ }^{14}$ Ralph Shanks, California Indian Baskets (Seattle, WA: University of Washington Press, 2010), 133.
} 
extreme, the smallest examples that fit on the head of a pin were made by Pomo weavers on the coast of Central California. ${ }^{15}$

A shopping basket with handle (Acc. No. 18/1582) is documented as the work of Dulcie Beal whose biography is published by Bates and Lee. Beal transformed a traditional twined openwork Miwok storage container of buckbrush into a shopping basket by adding a reinforced rim and handle that would appeal to a tourist. Could this be the same Yosemite Indian whose signature appears as "Dulcy" on the Indian Petition of 1891 ?

Contact also challenged traditional cultural values in the Indian community. When there was temptation and opportunity to sell baskets, burial rites might not include them and families were less likely to preserve collections as a measure of status.

Gertrude Hutchings' story is refreshing at the close of the nineteenth century because she had personal relationships with Indians as she lived and worked in Yosemite Valley; in contrast, contact between tourists and basket weavers was limited to transactions in the marketplace. Evidence of good relationships is suggested by one signature on the Indian Petition of 1891; "Cosey", the wife of Charlie Dick, was named after Gertrude "Cosie" Hutchings. One can deduce from Gertrude's career, collection and its documentation that she thought of the Indians as individuals. Also, her notes at the Peabody Institute conclude with the following oath: "These baskets are all obtained from the Indians who made and used them. Those from the Mono and Owens River country were packed mule-back across the Sierras to Yosemite by myself." 16

Gertrude's documentation of individual baskets is valuable because she identifies artists Dulcie Beal, Maria Bob and Mary Hamilton; acquisition locations at six Indian camps belonging to Blind Dick, Bob, Captain Alleck, Lucy, Mary, and Tony Williams; and many geographic locations. Of basket makers identified by Bates and Lee, could 'Mary' be the famous Miwok weaver who inherited leadership of the Yosemite Indian People? Could 'Lucy' be either Lucy Brown or Lucy Hite? Further research is needed to identify a body of work by individual artists.

Five years after Gertrude departed Yosemite in 1899, tourists had several options to acquire baskets. They could buy in person at concessions in Yosemite, order baskets to be delivered by the United States Postal Service, and request delivery by mail from art dealers.

\section{Basketry Post 1900}

After 1900, contact continued to have an impact locally and nationally. Unfortunately, some efforts were misled as they exploited both Indians and basket enthusiasts.

Citizens could learn the "lost art" of "a rapidly vanishing race" and weave "a real Indian basket" as "an entertaining pastime" in your own home with an instructional book Indian Basket Weaving: The Navajo School of Indian Basketry (1903) published by Whedon \& Spring

\footnotetext{
${ }^{15}$ Ralph Shanks, Indian Baskets of Central California (Seattle, WA: University of Washington Press, 2006), 56.

${ }^{16}$ Mills, Collection Notes, Accession Number 18, Robert S. Peabody Institute of Archaeology.
} 
Company of Los Angeles. ${ }^{17}$ The text is supplemented with numerous photographs of baskets from across the continent, including the Sierra Nevada. There is, however, no author and no explanation of the labor-intensive seasonal work of gathering and processing natural materials unique to each geographic region; rather, the enthusiast only needed to purchase raffia and rattan, imported from tropical countries.

George Wharton James (1858-1923) published Indian Basketry ${ }^{18}$ (1901) and How to Make Indian and Other Baskets (1903). ${ }^{19}$ He promoted teaching Indian basketry to adults, school teachers and children. In an attempt to organize basket enthusiasts nationwide, James offered membership in The Basket Fraternity with the following ambitious goals: encourage communication amongst members; develop a national basketry collection, traveling libraries, and lectures with stereopticon slides; and promote basket weaving classes in prisons, poor houses, and asylums. He wanted to revive the art of basket making among Indians while discouraging the use of aniline dyes, new designs, and crude workmanship. Finally, he wanted to influence the United States Government to require Indian girls to learn the art of basket weaving. His work blended facts, fantasy and romanticism.

James' approach was countered by anthropologist Otis Mason, Curator of Ethnography at the Smithsonian, who published the first meaningful attempt to analyze basket types in North America in Aboriginal American Indian Basketry (1904). ${ }^{20}$

From 1914 to 1918 , tourism declined because civilians were distracted by World War I and world politics. Yosemite National Park invented Indian Field Days to attract visitors with parades, competitive games, dancing, rodeos, and horse races. Indians were paid a few dollars to attend wearing regalia; however, in an effort to win sizable cash prizes in costume competitions, some individuals made creative ensembles or adopted Plains Indians styles with buckskin, feathers and beadwork. In yet another innovation in basketry, some basket makers imported glass beads and sewed beaded coverings for baskets, inspired by Plains Indians' designs.

Indian Field Day events were intended to encourage disappearing native skills including basketry. For example, prize money for basketry increased to $\$ 500$ in $1923 .{ }^{21}$ Unfortunately, events with no connection to Yosemite culture were condescending and only served to exploit the Indians. Without a concern for authenticity, the goal was entertainment and photogenic moments for tourists with Kodak Brownie cameras. In 1929 the Depression effectively halted Indian Field Days and the golden age of basket collecting came to an end.

In 1935 the United States Congress formed The Indian Arts and Crafts Board (IACB) to promote economic development. After the Department of Interior received a New Deal mandate from President Roosevelt to promote Indian arts and crafts, IACB supported an innovative exhibition "Indian Art of the United States" at the young but influential Museum of Modern Art in New York in 1941. Designed to link American Indian art —including basketry_ to modern art,

\footnotetext{
${ }^{17}$ Indian Basket Weaving: The Navajo School of Indian Basketry (Los Angeles, CA: Whedon \& Spring Co., 1903$) 7$.

${ }^{18}$ George Wharton James, Indian Basketry (New York, NY: Malkan, 1901).

${ }^{19}$ George Wharton James, How to Make Indian and Other Baskets (New York, NY: Henry Malkan, 1910).

${ }^{20}$ Otis Tufton Mason, Aboriginal American Indian Basketry (Santa Barbara, CA: Peregrine Smith, Inc., 1976).

${ }^{21}$ Bates and Lee, Tradition and Innovation, 95.
} 
contemporary design and modern decorative design, the effort also had ideological goals. At a time when America was searching for national values, struggling to emerge from the Depression and facing war in Europe, the exhibition was an opportunity to appropriate the story of the American Indians' strength and resilience in the face of adversity and "to highlight the essential Americanness of Indian art." The exhibition illustrates yet another exploitative dimension in the history of Euro-Americans taking a proprietary interest in Native American art in the twentieth century. ${ }^{22}$

\section{Decline and Revival of Basketry}

Basketry declined and thrived simultaneously due to contact. In Yosemite decline began in the mid-nineteenth century when contact with Euro-Americans progressively destroyed Indian culture and the need for traditional baskets. James Mason Hutchings observed in 1866 that "The younger Indians are not learning to make baskets... They begin to want trades, steadier work, more education, some live-stock, little gardens, orchards, farms..."23 Basket making reached its peak from 1890 to 1930 while supplying the marketplace in Yosemite Valley. The National Park Service periodically attempted to revive basketry by enlarging its Indian Cultural Programs and adding basketry exhibitions, but basket makers were scarce.

As basketry approached extinction in the late twentieth century, it was saved by the founding of American Indian basketry organizations nationwide that taught traditional techniques and business practices to members regardless of age or gender. Simultaneously, they collaborated with state and federal agencies to protect access to native plants and trees. Recognition must be given regionally to the California Indian Basketweavers Association, as well as to the Tohono O'odham Basketweavers Organization in the Southwest, Maine Indian Basket Alliance in the Northeast, Great Basin Native Basketweavers Association in the West and the Northwest Native American Basketweavers Association.

Indian art markets also deserve our attention because they encourage cultural preservation, intercultural understanding, and the careers of individual artists. In 2018, the Indian Market in Santa Fe, New Mexico, completed its ninety-sixth year, and the Heard Museum Indian Market in Phoenix, Arizona, completed its sixty-first year. In May 2018, the Abbe Museum in Maine opened its inaugural Indian Art Market, the first of its kind on the East Coast.

\section{Conclusion}

Yosemite Indian basketry in the nineteenth and early twentieth centuries was appreciated, promoted and exploited as a skill with economic, social and cultural value. Prior to contact, baskets connected Indian women to their ancestors, traditions and subsistence activities; after contact, new forms and designs linked Indian women to the world beyond Yosemite transcending the limitations of gender, geography and society.

\footnotetext{
${ }^{22}$ Jane Catherine Berlo, The Early Years of Native American Art History (Seattle, WA: University of Washington Press, 1992), 206.

${ }^{23}$ Bates and Lee, Tradition and Innovation, 37.
} 
The period from 1890 to 1930 was the peak of popularity for collecting basketry. American Indians experienced irreversible changes in the landscape, society, and governance; however, such changes did not detract from the ingenuity and artistry of basket makers. Creativity was clearly evident in basketry that was a blend of two cultures.

The juxtaposition of tradition and innovation that started in the nineteenth century continues today because basketry is a living art form. In the twenty-first century, basket makers as artists have reached a new level of expression that blends traditional techniques with personal innovation and the power to comment on environmental, social and political issues. Basketry has the power to bring the past to the present for personal and national reflection.

\section{Acknowledgements}

I wish to thank colleagues, friends and family who provided encouragement, shared knowledge and commented on drafts of this paper. At the Robert S. Peabody Institute of Archaeology, thank you to Ryan Wheeler, Director, and Marla Taylor, Curator of Collections. Thank you to Cassandra Goldwater, Ross Hunter and Rose Sculley. Finally, I am especially grateful to Ralph Shanks and Lisa Woo Shanks for recommending new directions for my research and visiting the Robert S. Peabody Institute of Archaeology to examine the Californian basketry collection. It has been a privilege to study these baskets closely and to try to trace their history and meaning.

\section{Bibliography}

Bates, Craig D. and Martha K. Lee. Tradition and Innovation: A Basket History of the Indians of the Yosemite-Mono Lake Area. Yosemite National Park, CA: The Yosemite Association, 1990.

Berlo, Jane Catherine. The Early Years of Native American Art History. Seattle, WA: University of Washington Press, 1992.

Bunnell, Lafayette H. Discovery of the Yosemite. New York, NY: F. H. Revell Company, 1892. http://www.yosemite.ca.us/library/discovery_of_the_yosemite/

Brandford, Joanne Segal. The North American Basket 1790-1967. Worcester, MA: Worcester Center for Crafts and Mercantile Press, 1976.

Bryant, William Cullen. Picturesque America or The Land We Live In, Volume 1. New York, NY: D. Appleton and Company, 1872.

Delaria, Philip. Playing Indian. New Haven, CT: Yale University Press, 1999.

Dunbar-Ortiz, Roxanne. An Indigenous Peoples' History of the United States. Boston, MA: Beacon Press, 2014.

Hutchings, James M. Scenes of Wonder and Curiosity in California. California, 1862. http://www.yosemite.ca.us/library/scenes_of_wonder_and_curiosity/

yosemite valley.html\#page 112 . In the Heart of the Sierras, 1881.

http://www.yosemite.ca.us/library/in_the_heart_of_the_sierras/

Indian Basket Weaving: The Navajo School of Indian Basketry. Los Angeles, CA: Whedon \& Spring Co., 1903.

James, George Wharton. How to Make Indian and Other Baskets. New York, NY: Henry 
Malkan, 1910.

. Indian Basketry. New York, NY: Malkan, 1901.

Kallenbach, Elizabeth A. The California Indian Basketweavers Association: Advocates for the Use of Museum Collections by Contemporary Weavers. Museum

Anthropology Review 3(1) Spring 2009. https://scholarworks.iu.edu/journals/ index.php/ mar/article/viewFile/103/182

Mason, Otis Tufton, Aboriginal American Indian Basketry. Santa Barbara, CA: Peregrine Smith, Inc., 1976.

Mills, Gertrude “Cosie” Hutchings. Collection Notes, Accession Number 18. Robert S. Peabody Institute of Archaeology.

Notes, Accession Number 18.

Sargent, Shirley. Pioneers in Petticoats: Yosemite's Early Women 1856-1900. Yosemite,

CA: Flying Spur Press, 1966. . Wawona's Yesterdays, 1961. http://www.yosemite.ca.us/library/wawonas_yesterday

Shanks, Ralph and edited by Lisa Woo Shanks. Indian Baskets of Central California.

Seattle, WA: University of Washington Press, 2006.

. California Indian Baskets. Seattle, WA: University of Washington Press, 2010. . Indian Baskets of Northern California and Oregon. Seattle, WA: University of Washington Press, 2015.

Smith, David S. California and the Indian Wars: The Mariposa War. San Jose University: The Burdick History Project. http://militarymuseum.org/Mariposa1.html.

Spence, Mark. Dispossessing the Wilderness: Yosemite Indians and the National Park Ideal, 1864-1930. Pacific Historical Review, Vol. 65, No. 1 (Feb., 1996), pp. 27-59. University of California Press http://jstor.org/stable/3640826

Turnbaugh, William and Sarah Peabody Turnbaugh. Baskets of the Grandmothers: American Indian Baskets in Myth and Legend. Peace Dale, RI: Thornbrook Publishing, 1999.

Wyckoff, Lydia L. Woven Worlds: Basketry from the Clark Field Collection at the Philbrook Museum of Art. Tulsa, OK: The Philbrook Museum of Art, 2001.

Yosemite Indian Petition to the United States, c. 1891. http://www.yosemite.ca.us/library/ yosemite_indian_petition_to_the_us.html 